\title{
Muscular weakness represents the main limiting factor of walk, functional independence and quality of life of myelopathy patients associated to HTLV-1
}

Fraqueza muscular representa o principal fator limitante da marcha, independência funcional e qualidade de vida de pacientes com mielopatia associada ao HTLV-1

Renata Costa Caiafaํ', Marco Orsini², Lilian R. Felicio ${ }^{3}$, Marzia Puccioni-Sohler1,4

\begin{abstract}
HTLV-1-associated myelopathy is a progressive disabling disease associated with gait abnormalities. Objective: To identify and quantify the main muscles affected by weakness and spasticity, their impact on gait, functional capacity and on quality of life of HTLV-1-associated myelopathy patients. Method: We evaluated lower limbs muscular strength according to the Medical Research Council scale, spasticity according to the modified Ashworth scale, daily activities according to the Barthel Index and quality of life according to the Short-Form Health Survey-36 of 26 HTLV-1-associated myelopathy patients. Results: The muscles most affected by weakness included the dorsal flexors and knee flexors. Spasticity predominated in the hip adductor muscles and in plantar flexors. Assistance for locomotion, minimal dependence in daily activities, limitations in functional capacity and physical aspects were the most common findings. Conclusion: The impairment of gait, functional dependence and quality of life were predominantly a consequence of intense muscle weakness in HTLV-1-associated myelopathy patients.
\end{abstract}

Keywords: HAM/TSP; functional ability; gait; quality of life.

RESUMO

Mielopatia associada ao HTLV-1 é uma doença inflamatória, incapacitante e progressiva que acomete o sistema nervoso central. Objetivo: Identificar e quantificar os principais músculos comprometidos pela fraqueza e espasticidade, o impacto na capacidade funcional e na qualidade de vida dos pacientes com mielopatia associada ao HTLV-1. Método: Força muscular (Medical Research Council), espasticidade (escala Ashworth modificada), atividades de vida diária (Índice de Barthel) e qualidade de vida (Short-Form Health Survey-36) foram avaliados em 26 pacientes. Resultados: Os principais músculos comprometidos pela fraqueza incluíram os flexores dorsais e flexores do joelho. A espasticidade predominou nos músculos adutores do quadril e nos flexores plantares. Assistência para locomoção, dependência mínima nas atividades diárias, limitações na capacidade funcional e os aspectos físicos representaram os achados mais frequentes. Conclusão: Dificuldade de deambulação, dependência funcional e prejuízo na qualidade de vida foram as principais consequências da intensa fraqueza muscular nos pacientes com mielopatia associada ao HTLV-1.

Palavras-chave: HAM/TSP; avaliação funcional; marcha; qualidade de vida.

HTLV-1 associated myelopathy/tropical spastic paraparesis (HAM/TSP) is a chronic demyelinating inflammatory neurological disease of the central nervous system $(\mathrm{CNS})^{1}$. The development of neurological disability occurs between the ages of 20 and 70, predominantly among women ${ }^{1,2}$. It is estimated that approximately 5-10 million people are infected worldwide with HTLV-I ${ }^{3}$. It may be considered a neglected disease ${ }^{4}$. Five percent of HTLV-1 seropositive individuals develop neurological disorder ${ }^{1}$.

${ }^{1}$ Universidade Federal do Rio de Janeiro, Pós-Graduação em Doenças Infecciosas e Parasitárias, Rio de Janeiro RJ, Brazil;

${ }^{2}$ Centro Universitário Augusto Motta, Pós-Graduação em Ciências de Reabilitação, Rio de Janeiro RJ, Brazil;

${ }^{3}$ Universidade Federal de Uberlândia, Faculdade de Fisioterapia, Uberlandia MG, Brazil;

«Universidade Federal do Rio de Janeiro, Hospital Universitário Gaffree \& Guinle, Pós-Graduação em HIV/AIDS e Hepatite Viral, Rio de Janeiro RJ, Brazil.

Correspondence: Renata Costa Caiafa; Universidade Federal do Estado do Rio de Janeiro; Rua Mariz e Barros, 775; 22270-004 Rio de Janeiro RJ, Brasil;

E-mail:renata.caiafa@bol.com.br

Conflict of interest: There is no conflict of interest to declare.

This work was supported by Fundação de Amparo à Pesquisa do Estado do Rio de Janeiro (FAPERJ) and a Msc fellowship from Coordenação de Aperfeicoamento de Pessoal de Nivel Superior (CAPES) to R.C.C.

Received 21 March 2015; Received in final form 15 August 2015; Accepted 30 November 2015. 
The diagnosis of HAM/TSP is based on clinical findings and presence of anti-HTLV-1 antibodies in serum and cerebrospinal fluid $(\mathrm{CSF})^{1}$. The disease is characterized by weakness and muscle spasticity in the lower limbs with insidious onset. Neurogenic bladder and bowel disorders, sexual dysfunction and back pain have been also reported $^{1,2}$. Reduced muscle strength, spasticity, old age, back pain and long disease duration may interfere in the gait ${ }^{5}$. Ten years after the onset of symptoms, $45 \%$ of patients required assistance for locomotion ${ }^{6}$. All these manifestations may affect the quality of life of HAM/TSP patients ${ }^{7}$. There are few studies documenting specific motor deficits in individuals with HAM/TSP 5 .

The functional evaluation of daily life activities is very important for rehabilitation process of HAM/TSP patients. Furthermore, measuring of spasticity, strength and power are crucial in identifying motor deficits and establishing the early physical therapy approach, which aim to manage ambulatory difficulties and avoid loss of quality of life and promote functional independence of these patients. The purpose of this study was to identify and quantify the specific affected lower limb muscles and its impact on gait (wheelchair vs. ambulatory status), functional activities and on the quality of life of HAM/TSP patients.

\section{METHOD}

\section{Subjects}

Twenty-six out of $52 \mathrm{HAM}$ /TSP patients were selected prospectively, from September 2012 to August $2013^{1}$. All patients presented anti-HTLV-1 antibodies (ELISA test in serum and cerebrospinal fluid, confirmed by Western blot in serum). All were using medication for spasticity (baclofen, $10 \mathrm{mg}, 3$ times a day) for more than three months. The exclusion criteria included presence of pain or muscle retractions, spinal cord compression syndrome, cognitive impairment, co-infection with HIV, hepatitis $\mathrm{C}$ virus or syphilis, vitamin B12 deficiency, autoimmune diseases, hyperthyroidism and under any physical therapy treatment. The institutional ethics committee approved this study. All the patients signed informed consent.

\section{Muscle examination}

Eleven lower limb muscles were evaluated. These included muscle of the hip joint (flexors, extensors, abductors and adductors), knee joint (flexors and extensors), ankle joint (dorsalis flexor, plantar flexors and evertor) and fingers joint (finger extensors and extensor hallucis).

\section{Strength and spasticity scales}

Medical Research Council (MRC). To evaluate the degree of lower limb muscles strength, we used the MRC system for manual muscle testing $(\mathrm{MMT})^{8,9}$. The graduation
MRC system consists of $0=$ no contraction; 1 = a flicker or trace of contraction; 2 = active movement with gravity eliminated; 3 = active movement against gravity; 4 = active movement against gravity and resistance; $5=$ normal contraction ${ }^{8}$.

Modified Ashworth scale. The spasticity was measured by modified Ashworth scale that involves manual movement of the limb through the range of motion (ROM) to passively stretch specific muscle groups. The classification of this scale included: $0=$ no increase in muscle tone; 1 = slight increase in muscle tone, manifested by a catch and release or by minimal resistance at the end range of motion when the affected part(s) is moved in flexion or extension; 1+ = slight increase in muscle tone, manifested by a catch, followed by minimal resistance throughout the remainder (less than half) of the ROM; 2 = marked increase in muscle tone through most of the ROM, but affected part(s) easily moved; 3 = considerable increase in muscle tone, passive movement difficult; $4=$ affected part(s) rigid in flexion or extension ${ }^{10,11}$.

\section{Functional evaluation}

The Barthel Index was used to evaluate 10 items regarding the capacity to conduce daily activities. Each item was measured in 0 to 5 or 10 , and then the individual items were summed. In relation to the sum: 0 indicated total dependence; 5 to 25 , severe dependence; 30 to 55 moderate dependence; 60 to 95 minimal dependence; and 100 independence ${ }^{12}$.

\section{Quality of life}

The Short-form health survey 36 (SF-36) was used to evaluate the quality of life. It consists of 36 items organized in eight domains: D1 - physical functioning, D2 - role-physical functioning, D3 - bodily pain, D4 - general health, D5 - vitality, D6 - social functioning, D7 - role-emotional functioning and D8 - mental health. The total score ranges from zero (worst) to 100 (best). Results above 50 indicate good quality of life and below 50, bad quality of life ${ }^{13}$.

\section{Statistical analysis}

Considering that the majority of the patients had trouble walking and using public transportation, this study used a convenience group. The Shapiro-Wilk test for normality assessed whether the data presented Gaussian distribution. According to data distribution, Pearson's or Spearman's tests were used. We evaluated the strength and spasticity degree between right and left lower limbs by Wilcoxon matched pairs test, and proportion of abnormality by McNemar test. Kappa coefficient verified the concordance level among the instruments. Kappa values range from 0 to 1 . The meaning of these values are expressed as 0 poor concordance, 0.1 to 0.2 discrete concordance, 0.21 to 0.4 considerable concordance, 0.41 to 0.6 moderate concordance, 0.61 to 0.8 substantial concordance, 0.81 to 1 excellent concordance. The significance level was set at $0.05(5 \%)$. 


\section{RESULTS}

Among 26 HAM/TSP patients, 16 (61.5\%) were female, median age of 56 (range: $39-70$ yrs. old). The time of the symptoms ranged from 6 months to 29 years (median $=8$ years). The most common symptoms at the onset of the disease included lower limb muscle weakness in 21 (84\%) patients and sphincter disturbance in $20(77 \%)$ patients. Two patients reported lower back pain (Table 1). The majority (92.3\%) needed assistance for locomotion. Tables 2 and 3 show muscle strength (MRC) and spasticity (Ashworth modified scale) quantitative measurements. The majority of the studied muscle groups displayed active movement with gravity eliminated ( $\mathrm{MRC}=2$ ), except for knee flexors and left tibialis anterior (dorsalis flexor) $(\mathrm{MRC}=1)$. Few muscles presented normal power (Table 2). The worst median spasticity predominated in bilateral hip adductors and plantar flexors groups (Table 3). There was no statistical difference between right and left muscles strength and spasticity (Tables 2 and 3).

All patients had weakness in at least one muscle group, mostly in the right side (Table 4). The majority of lower limb proximal muscles were weak. Spasticity was more common in hip adductors (77\% bilaterally) and plantar flexors (left $-88.5 \%$ and right $-84.6 \%$ ) (Table 4). The majority of patients had normal tonus in hip extensor (85\%), hip abductors (77\%) and knee flexors (left $-54 \%$ and right $-42 \%$ ) (Table 4).

Forty two percent of the cases were restricted to wheelchairs. There were significant differences in muscular strength between the patients restricted and non-restricted to wheelchair ( $p \leq 0.05$ ), except for the left plantar flexor muscle (Table 5). In the spasticity evaluation, there was no significant difference between the two groups (Table 6).

The functional evaluation (Barthel Index) showed median of 70 (range: $20-100$ ) in the 26 HAM/TSP patients, indicating minimal dependence during daily activities. The majority of patients (69\%) demonstrated minimal dependency, 15\% moderate dependence, $8 \%$ severe dependence and $8 \%$ were independent. The Figure shows the proportion of the cases and the performed functional activities on Barthel Index. The greatest difficulties included mobility, ascending and descending stairs and bladder control.

In relation to quality of life, Table 7 shows median and range of the SF-36 survey. From the eight domains, physical functioning (D1) and role-physical functioning (D2) had the lowest scores.

\section{Correlation between clinical characteristics, functional abilities and quality of life}

The functional evaluation (Barthel) demonstrated correlation with reduced muscle strength bilaterally $(r=0.6$; $\mathrm{p} \leq 0.001$ ), indicating that there was a relationship between muscle weakness and dependence during daily activities. No statistical correlation was observed between the functional evaluation (Barthel) and muscle tone.
There was correlation between reduced muscle strength bilaterally and the domains physical functioning $(r=0.422$; $\mathrm{p}=0.03)$ and social functioning $(\mathrm{r}=0.41 ; \mathrm{p}=0.04)$ of life quality. The muscular tonus did not show statistical correlation with life quality (SF-36).

Table 1. Clinical and epidemiological findings in 26 HAM/TSP patients.

\begin{tabular}{|c|c|c|c|c|c|}
\hline Patients & Sex & Age & $\begin{array}{c}\text { Duration } \\
\text { of disease } \\
\text { (years) }\end{array}$ & $\begin{array}{c}\text { Assistance to } \\
\text { walk }\end{array}$ & $\begin{array}{c}\text { Symptoms of } \\
\text { onset }\end{array}$ \\
\hline 1 & $\mathrm{~F}$ & 49 & 0.5 & Wheelchair & $\begin{array}{l}\text { Lower limb } \\
\text { weakness }\end{array}$ \\
\hline 2 & M & 62 & 2 & $\begin{array}{l}\text { Unilateral } \\
\text { support }\end{array}$ & $\begin{array}{l}\text { Lower limb } \\
\text { weakness }\end{array}$ \\
\hline 3 & M & 56 & 4 & $\begin{array}{l}\text { Bilateral } \\
\text { support }\end{array}$ & $\begin{array}{l}\text { Low back } \\
\text { pain }\end{array}$ \\
\hline 4 & $F$ & 70 & 4 & Wheelchair & $\begin{array}{l}\text { Lower limb } \\
\text { weakness }\end{array}$ \\
\hline 5 & $F$ & 48 & 4 & Independence & $\begin{array}{l}\text { Lower limb } \\
\text { weakness }\end{array}$ \\
\hline 6 & $F$ & 54 & 5 & $\begin{array}{l}\text { Bilateral } \\
\text { support }\end{array}$ & $\begin{array}{l}\text { Lower limb } \\
\text { weakness }\end{array}$ \\
\hline 7 & M & 61 & 7 & $\begin{array}{l}\text { Unilateral } \\
\text { support }\end{array}$ & $\begin{array}{l}\text { Lower limb } \\
\text { weakness }\end{array}$ \\
\hline 8 & $F$ & 47 & 7 & $\begin{array}{l}\text { Unilateral } \\
\text { support }\end{array}$ & $\begin{array}{l}\text { Lower limb } \\
\text { weakness }\end{array}$ \\
\hline 9 & $F$ & 46 & 7 & Wheelchair & $\begin{array}{l}\text { Lower limb } \\
\text { weakness }\end{array}$ \\
\hline 10 & M & 56 & 8 & $\begin{array}{l}\text { Unilateral } \\
\text { support }\end{array}$ & $\begin{array}{l}\text { Lower limb } \\
\text { weakness }\end{array}$ \\
\hline 11 & M & 59 & 8 & $\begin{array}{l}\text { Unilateral } \\
\text { support }\end{array}$ & $\begin{array}{l}\text { Lower limb } \\
\text { weakness }\end{array}$ \\
\hline 12 & F & 61 & 8 & $\begin{array}{l}\text { Unilateral } \\
\text { support }\end{array}$ & $\begin{array}{l}\text { Lower limb } \\
\text { weakness }\end{array}$ \\
\hline 13 & $F$ & 62 & 8 & $\begin{array}{l}\text { Unilateral } \\
\text { support }\end{array}$ & $\begin{array}{c}\text { Low back } \\
\text { pain }\end{array}$ \\
\hline 14 & $F$ & 49 & 9 & Wheelchair & $\begin{array}{l}\text { Lower limb } \\
\text { weakness }\end{array}$ \\
\hline 15 & M & 51 & 10 & Wheelchair & $\begin{array}{l}\text { Lower limb } \\
\text { weakness }\end{array}$ \\
\hline 16 & $F$ & 54 & 10 & Independence & $\begin{array}{l}\text { Lower limb } \\
\text { rigidity }\end{array}$ \\
\hline 17 & M & 63 & 13 & $\begin{array}{c}\text { Unilateral } \\
\text { support }\end{array}$ & $\begin{array}{l}\text { Lower limb } \\
\text { weakness }\end{array}$ \\
\hline 18 & M & 46 & 13 & Wheelchair & $\begin{array}{l}\text { Lower limb } \\
\text { weakness }\end{array}$ \\
\hline 19 & $F$ & 61 & 14 & Wheelchair & $\begin{array}{l}\text { Lower limb } \\
\text { weakness }\end{array}$ \\
\hline 20 & M & 70 & 14 & $\begin{array}{l}\text { Unilateral } \\
\text { support }\end{array}$ & Imbalance \\
\hline 21 & F & 49 & 19 & Wheelchair & $\begin{array}{l}\text { Lower limb } \\
\text { weakness }\end{array}$ \\
\hline 22 & F & 70 & 20 & $\begin{array}{l}\text { Unilateral } \\
\text { support }\end{array}$ & $\begin{array}{l}\text { Lower limb } \\
\text { weakness }\end{array}$ \\
\hline 23 & $F$ & 39 & 20 & Wheelchair & $\begin{array}{l}\text { Lower limb } \\
\text { weakness }\end{array}$ \\
\hline 24 & $F$ & 63 & 22 & Wheelchair & $\begin{array}{l}\text { Lower limb } \\
\text { dormancy }\end{array}$ \\
\hline 25 & $F$ & 55 & 23 & $\begin{array}{l}\text { Unilateral } \\
\text { support }\end{array}$ & $\begin{array}{l}\text { Lower limb } \\
\text { weakness }\end{array}$ \\
\hline 26 & M & 61 & 29 & Wheelchair & $\begin{array}{l}\text { Lower limb } \\
\text { weakness }\end{array}$ \\
\hline
\end{tabular}

F: Female; M: male. 
Table 2. Muscle strength (MRC) in 26 HAM/TSP patients.

\begin{tabular}{lccc}
\hline \multirow{2}{*}{ Muscles } & \multicolumn{2}{c}{ Median (range) } & \multirow{2}{*}{ p-value } \\
\cline { 2 - 3 } & Left & Right & \\
\hline Hip flexor & $2(0-4)$ & $2(0-4)$ & 0.99 \\
Hip extensor & $2(0-5)$ & $2(0-5)$ & 0.99 \\
Hip abductors & $2(0-4)$ & $2(0-3)$ & 0.99 \\
Hip adductors & $2(0-5)$ & $2(0-4)$ & 0.58 \\
Knee extensors & $3(0-5)$ & $3(0-5)$ & 0.57 \\
Knee flexors & $1(0-5)$ & $1(0-4)$ & 0.58 \\
Dorsal flexors & & & \\
$\quad$ Tibialis anterior & $1(0-5)$ & $2(0-5)$ & 0.89 \\
Ankle evertor & & & \\
$\quad$ Long and short fibular & $2(0-4)$ & $2(0-4)$ & 0.58 \\
Plantar flexors & $3(0-5)$ & $3(0-5)$ & 0.17 \\
Finger extensors & & & \\
$\quad$ Finger extensor & $2(0-5)$ & $2(0-5)$ & 0.99 \\
$\quad$ Extensor do halluces & $3(0-5)$ & $3(0-5)$ & 0.99 \\
\hline
\end{tabular}

Table 3. Muscle spasticity (Ashworth modificated) in 26 HAM/TSP patients.

\begin{tabular}{lccc}
\hline \multirow{2}{*}{ Muscles } & \multicolumn{2}{c}{ Median (range) } & \multirow{2}{*}{ p-value } \\
\cline { 2 - 3 } & Left & Right & \\
\hline Hip flexor & $1(0-4)$ & $1(0-4)$ & 0.19 \\
Hip extensors & $0(0-4)$ & $0(0-4)$ & 0.99 \\
Hip abductors & $0(0-4)$ & $0(0-4)$ & 0.99 \\
Hip adductors & $2(0-4)$ & $2(0-4)$ & 0.99 \\
Knee extensors & $1(0-4)$ & $1(0-4)$ & 0.26 \\
Knee flexors & $0(0-4)$ & $0(0-4)$ & 0.99 \\
Dorsal flexors & & & \\
$\quad$ Tibialis anterior & $1(0-4)$ & $1(0-4)$ & 0.34 \\
Ankle evertor & & & \\
$\quad$ Long and short fibular & $0(0-4)$ & $0(0-4)$ & 0.50 \\
Plantar flexors & $2(0-4)$ & $2(0-4)$ & 0.77 \\
$\begin{array}{l}\text { Finger extensors } \\
\quad \text { Finger extensor }\end{array}$ & $1(0-4)$ & $1+(0-4)$ & 0.50 \\
\hline Extensor do hallucis & $1(0-4)$ & $1+(0-4)$ & 0.20 \\
\hline
\end{tabular}

Table 4. Frequency of muscle weakness and spasticity in 26 HAM/TSP patients.

\begin{tabular}{|c|c|c|c|c|c|c|}
\hline & \multicolumn{3}{|c|}{ Weakness } & \multicolumn{3}{|c|}{ Spasticity } \\
\hline & \multicolumn{2}{|c|}{ Abnormal n (\%) } & \multirow{2}{*}{$p$-value } & \multicolumn{2}{|c|}{ Abnormal n (\%) } & \multirow{2}{*}{$p$-value } \\
\hline & Left & Right & & Left & Right & \\
\hline Hip flexors & $26(100)$ & $26(100)$ & 0.50 & $17(65)$ & $16(62)$ & 0.99 \\
\hline Hip extensors & $23(89)$ & $26(100)$ & 0.99 & $4(15)$ & $4(15)$ & 0.99 \\
\hline Hip abductors & $26(100)$ & $26(100)$ & 0.99 & $6(23)$ & $6(23)$ & 0.99 \\
\hline Hip adductors & $25(96)$ & $26(100)$ & 0.99 & $20(77)$ & $20(77)$ & 0.99 \\
\hline Knee extensors & $22(85)$ & $22(85)$ & 0.99 & $16(62)$ & $15(58)$ & 0.99 \\
\hline Knee flexors & $25(96)$ & $26(100)$ & 0.99 & $12(46)$ & $11(58)$ & 0.99 \\
\hline Dorsal flexors & $23(89)$ & $24(92)$ & 0.50 & $14(54)$ & $14(54)$ & 0.99 \\
\hline Ankle evertor & $21(81)$ & $21(81)$ & 0.99 & $5(19)$ & $4(15)$ & 0.99 \\
\hline Plantar flexor & $21(81)$ & $23(89)$ & 0.99 & $23(89)$ & $22(85)$ & 0.50 \\
\hline Finger extensors & $25(96)$ & $25(96)$ & 0.99 & $18(69)$ & $19(73)$ & 0.99 \\
\hline
\end{tabular}

The measurement of functional evaluation (Barthel) demonstrated correlation with the domains physical functioning $(r=0.6$; $\mathrm{p}=0.001)$ and social functioning $(\mathrm{r}=0.524 ; \mathrm{p}=0.006)$ of SF-36 survey. There was no correlation between the Barthel Index, duration of the disease $(r=-0.279 ; p=0.17)$ and age $(r=0.016 ; p=0.490)$.

\section{DISCUSSION}

This study identified and quantified the muscle groups compromised by weakness and spasticity as measured by modified Ashworth scale in lower limbs and its influence on activities of daily living and quality of life of patients with HAM/TSP. In addition, this report attempts to evaluate whether hypertonicity or weakness better predicts the need for a wheelchair.

\section{Weakness and tonus}

The results show intense weakness in the lower limbs, assessed by manual muscle testing (MMT) in all groups evaluated.
The highest frequency of muscle strength loss occurred bilaterally in the hip flexors, hip abductors, plantar flexors and finger extensors. Difference was found in muscle strength of the wheelchair patients group compared to non-wheelchair which suggests that muscle weakness is the most damaging factor in the active movement of these individuals, thus determining the restriction of patients to wheelchairs. Muscle tonus was not as strongly involved as weakness in the majority of the lower limb muscle groups. Therefore, factor was not responsible for the motion restriction observed in most individuals. Only two muscle groups, hip adductors and plantar flexors, showed significantly more intense spasticity. However, it has not directly influenced the restriction of patients to wheelchairs.

\section{Functional abilities}

In the assessment of functional abilities based on Barthel Index, minimal functional dependence was found in the majority of the patients with HAM/TSP similar to previous study ${ }^{14}$. Although HAM/TSP is a severe and disabling 
Table 5. Comparison of strength between HAM/TSP patients restricted to wheelchair and not restricted to wheelchair.

\begin{tabular}{|c|c|c|c|c|}
\hline Muscle & & $\begin{array}{c}\text { RW } \\
\text { Median } \\
\text { (range) }\end{array}$ & $\begin{array}{c}\text { NRW } \\
\text { Median } \\
\text { (range) }\end{array}$ & $p$-value \\
\hline \multicolumn{5}{|l|}{ Strenght } \\
\hline \multirow{2}{*}{ Hip flexor } & Left & $1(0-2)$ & $3(1-4)$ & 0.002 \\
\hline & Right & $1(0-2)$ & $3(1-4)$ & $<0.001$ \\
\hline \multirow{2}{*}{ Hip extensor } & Left & $1(0-2)$ & $3(1-5)$ & $<0.001$ \\
\hline & Right & $1(0-2)$ & $3(1-5)$ & $<0.001$ \\
\hline \multirow{2}{*}{ Hip abductor } & Left & $1(0-2)$ & $2(1-4)$ & 0.002 \\
\hline & Right & $1(0-2)$ & $2(1-3)$ & 0.001 \\
\hline \multirow{2}{*}{ Hip adductor } & Left & $1(0-3)$ & $2(1-5)$ & 0.003 \\
\hline & Right & $1(0-3)$ & $2(1-4)$ & 0.02 \\
\hline \multirow{2}{*}{ Knee extensor } & Left & $1(0-4)$ & $4(2-5)$ & 0.005 \\
\hline & Right & $1(0-4)$ & $4(2-5)$ & $<0.001$ \\
\hline \multirow{2}{*}{ Knee flexor } & Left & $1(0-2)$ & $3(0-5)$ & 0.006 \\
\hline & Right & $1(0-2)$ & $2(0-4)$ & 0.01 \\
\hline \multicolumn{5}{|l|}{ Dorsal flexors } \\
\hline \multirow{2}{*}{ Tibialis anterior } & Left & $1(0-4)$ & $3(1-5)$ & 0.003 \\
\hline & Right & $1(0-2)$ & $3(1-5)$ & 0.003 \\
\hline \multicolumn{5}{|l|}{ Ankle evertor } \\
\hline \multirow{2}{*}{$\begin{array}{l}\text { Long and short } \\
\text { fibular }\end{array}$} & Left & $1(0-2)$ & $4(1-4)$ & $<0.001$ \\
\hline & Right & $1(0-2)$ & $4(1-4)$ & $<0.001$ \\
\hline \multirow{2}{*}{ Plantar flexor } & Left & $1(0-5)$ & $4(1-5)$ & 0.06 \\
\hline & Right & $1(0-4)$ & $3(1-5)$ & 0.01 \\
\hline \multicolumn{5}{|l|}{ Finger extensors } \\
\hline \multirow{2}{*}{ Finger extensors } & Left & $1(0-4)$ & $3(1-5)$ & 0.006 \\
\hline & Right & $1(0-4)$ & $3(1-5)$ & 0.001 \\
\hline \multirow{2}{*}{$\begin{array}{l}\text { Extensor do } \\
\text { hallucis }\end{array}$} & Left & $1(0-5)$ & $3(1-4)$ & 0.004 \\
\hline & Right & $1(0-5)$ & $3(1-4)$ & 0.006 \\
\hline
\end{tabular}

Restricted to Wheelchair; NRW: Not Restricted to Wheelchair.
Table 6. Comparison of spasticity between HAM/TSP patients restricted to wheelchair and not restricted to wheelchair.

\begin{tabular}{|c|c|c|c|c|}
\hline Muscle & & $\begin{array}{c}\mathrm{RW} \\
\text { Median } \\
\text { (range) }\end{array}$ & $\begin{array}{l}\text { NRW } \\
\text { Median } \\
\text { (range) }\end{array}$ & $p$-value \\
\hline \multicolumn{5}{|l|}{ Spasticity } \\
\hline \multirow{2}{*}{ Hip flexor } & Left & $1+(0-4)$ & $0(0-3)$ & 0.053 \\
\hline & Right & $2(0-4)$ & $0(0-3)$ & 0.639 \\
\hline \multirow{2}{*}{ Hip extensor } & Left & $0(0-3)$ & $0(0-1)$ & 0.148 \\
\hline & Right & $0(0-3)$ & $0(0-1)$ & 0.148 \\
\hline \multirow{2}{*}{ Hip abductor } & Left & $0(0-4)$ & $0(0-3)$ & 0.149 \\
\hline & Right & $0(0-4)$ & $0(0-3)$ & 0.149 \\
\hline \multirow{2}{*}{ Hip adductor } & Left & $3(0-4)$ & $1+(0-3)$ & 0.023 \\
\hline & Right & $3(0-4)$ & $1+(0-3)$ & 0.023 \\
\hline \multirow{2}{*}{ Knee extensor } & Left & $1+(0-4)$ & $1(0-3)$ & 0.187 \\
\hline & Right & $1+(0-4)$ & $1(0-3)$ & 0.122 \\
\hline \multirow{2}{*}{ Knee flexor } & Left & $0(0-4)$ & $0(0-2)$ & 0.151 \\
\hline & Right & $0(0-4)$ & $0(0-2)$ & 0.122 \\
\hline \multicolumn{5}{|l|}{ Dorsal flexors } \\
\hline \multirow{2}{*}{$\begin{array}{l}\text { Tibialis } \\
\text { anterior }\end{array}$} & Left & $1(0-4)$ & $1(0-3)$ & 0.615 \\
\hline & Right & $1(0-4)$ & $1(0-3)$ & 0.825 \\
\hline \multicolumn{5}{|l|}{ Ankle evertor } \\
\hline \multirow{2}{*}{$\begin{array}{l}\text { Long and short } \\
\text { fibular }\end{array}$} & Left & $0(0-4)$ & $0(0-2)$ & 0.181 \\
\hline & Right & $0(0-4)$ & $0(0-1+)$ & 0.064 \\
\hline \multirow{2}{*}{ Plantar flexor } & Left & $2(0-4)$ & $1+(0-3)$ & 0.138 \\
\hline & Right & $3(0-4)$ & $1+(0-3)$ & 0.221 \\
\hline \multicolumn{5}{|l|}{ Finger extensors } \\
\hline \multirow{2}{*}{$\begin{array}{l}\text { Finger } \\
\text { extensors }\end{array}$} & Left & $1+(0-4)$ & $1(0-2)$ & 0.255 \\
\hline & Right & $1+(0-4)$ & $1(0-2)$ & 0.221 \\
\hline \multirow{2}{*}{$\begin{array}{l}\text { Extensor do } \\
\text { hallucis }\end{array}$} & Left & $1+(0-4)$ & $1(0-2)$ & 0.075 \\
\hline & Right & $1+(0-4)$ & $1(0-3)$ & 0.278 \\
\hline
\end{tabular}

Restricted to Wheelchair; NRW: Not Restricted to Wheelchair.

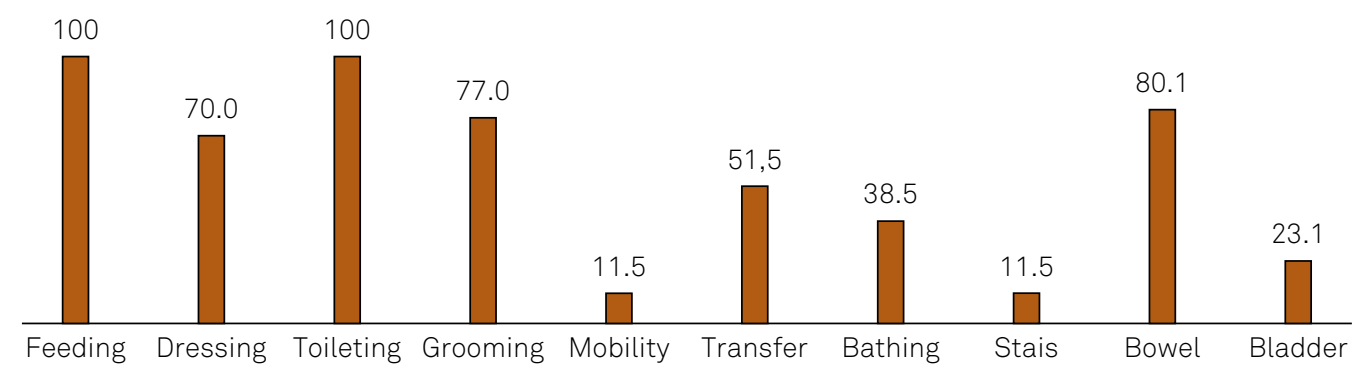

(\%)

Figure. The independent execution of functional tasks on Barthel Index in 26 HAM/TSP cases.

neurological disease, mild dependence in carrying out daily activities can be explained by the lack of concomitant involvement of upper limbs. There was a correlation between muscle strength impairment (MRC) and ability to perform daily activities (Barthel Index). This finding suggests that muscle weakness interferes with the functional independence of HAM/TSP patients. On the other hand, no correlation was observed between the degree of spasticity (Ashworth modified) and functional ability in daily activities (Barthel). This can be explained by the fact that most of the muscle groups had normal tonus or slight spasticity. The most important limitations in quality of life were related to physical function and role-physical function. These two domains showed moderate correlation with the Barthel Index, considering that these aspects were impaired by motor incapacity.

\section{Gait impairment}

This study highlights that gait impairment was determined mainly by weakness of the lower limbs compared to spasticity. This fact is justified by the difference found in 
Table 7. Quality of life (SF-36) in 26 HAM/TSP cases.

\begin{tabular}{lccc}
\hline Domínios (D) & $\begin{array}{c}\text { Median } \\
\text { (range) }\end{array}$ & p-value & $95 \% \mathrm{Cl}$ \\
\hline D1. Physical functioning & $0(0-45)$ & 0.07 & $5.1-18.3$ \\
\hline D2. Role-physical functioning & $25(0-100)$ & $\leq 0.001$ & $21.3-57.5$ \\
\hline D3. Pain & $50(0-100)$ & 0.50 & $40.9-63.7$ \\
\hline D4. General health & $57(20-92)$ & 0.70 & $52.9-68.4$ \\
\hline D5. Vitality & $55(5-100)$ & 0.90 & $47.3-66.5$ \\
\hline D6. Social functioning & $63(0-100)$ & 0.01 & $49.1-77.8$ \\
\hline D7. Role-emotional functioning & $100(0-100)$ & 0.004 & $48.0-85.3$ \\
D8. Mental health & $60(16-100)$ & 0.55 & $51.6-71.4$ \\
\hline
\end{tabular}

reduced muscle strength in the patients restricted to wheelchairs compared to ambulatory patients. The intense hypertonicity observed in the hip adductors and plantar flexor muscle groups did not directly influence the restriction of patients to wheelchairs, but they may be responsible for compromise of the antagonist muscle strength by disuse ${ }^{15}$. The spasticity of adductors can be responsible for abductor weakness causing enhanced swing of the pelvis during ambulation phase and consequent gait instability ${ }^{16}$. Otherwise, a previous study showed a strong correlation between community ambulation and plantar flexors and knee extensors strength ${ }^{5}$. In fact, the reduced strength impairs gait capacity and gradually interferes on the need for locomotion assistance, starting with unilateral support until the wheelchair. Ten years after disease onset, $30 \%$ of patients are bedridden and $45 \%$ need some assistance for walking ${ }^{6}$ Biomechanical changes related to weakness and spasticity can contribute to imbalance and falls, leading to gradual loss of the ability to walk. Gait restriction can generate a vicious cycle of inactivity and consequently increase muscle weakness.

\section{Assessment of individual muscles strength and spasticity}

Assessment of individual muscles strength and spasticity represents a challenge, since the measurement of both is difficult to discriminate in people with neurological impairments. However, it was observed that the most important weakness (dorsalis flexor and knee flexor muscles) in the studied patients did not correspond to the muscles most affected by spasticity (hip adductor groups and plantar flexor), allowing for the assessment of muscle strength and resting tonus. The use of antispasmodic drugs for all patients may have induced a reduction in spasticity and made it easier to evaluate muscle strength. The hip adductor groups and plantar flexor showed significant degree of spasticity, even taking the drug, indicating that these groups have a higher involvement.

\section{Walking ability and dependence during activities}

The association of muscle changes found in our study may explain the loss of walking ability and dependence conducting daily activities. Another aspect is spasticity of plantar flexors, which can restrict the dorsiflexors, both contributing to changes in the stance phase and swing. In the stance phase, initial foot is impaired causing a shortening of step, knee hyperextension and pelvic tilt, spending more energy at gait. In the swing phase, disability of knee flexion occurs with consequent drag toe, shortening the stride and reducing gait velocity ${ }^{17}$. Associated with this, hip adductor spasticity and weakness of the abductor generate an exaggerated lateral pelvic tilt and imbalance during gait ${ }^{16}$. The correlation found in our study between the impairment of muscle strength (MRC) of the patients and their ability to perform daily ctivities (Barthel) reinforces the argument that muscle weakness interferes in the functional abilities of patients with HAM/TSP. The lack of correlation between the degree of spasticity and functional dependence in daily activities occurs due to discrete tonus increase in the most of the examined muscles. In a paretic limb, the spasticity may help in certain functions, such as walking, standing and during transfers ${ }^{18}$.

The correlation between functional abilities (Barthel index) and the domains of functional capacity and social aspects (SF 36) suggest that motor impairment has a social impact on the quality of life of these individuals. On the other hand, a previous study showed that physical limitations of the disease also determine emotional impact on the quality of life of patients with HAM/TSP ${ }^{19}$. Here the most important limitations in the quality of life were related to physical functioning and role-physical functioning, also consistent with the literature ${ }^{20}$.

\section{Limitations of this study}

Limitations of this analysis occur due to the relatively small number of subjects. Although there are millions of people infected by HTLV-1 in the world, only $5 \%$ of infected individuals develop neurological disease, thus rendering it an underdiagnosed and negligible disease $e^{4}$. In addition, the physical limitations resulting from gait disturbance and trouble with the access to public transportation difficult the neurological diagnosis, monitoring and follow up of the patients in developing countries. There is no specific treatment for the virus, the prognosis of HAM/TSP is poor and often brings up a disastrous impact on patients' lives. The financial and social costs to the patient, their family and to the health care system can be intense due to the fact that it is a chronic progressive disease. Thus, the elaboration of public policies on education and prophylaxis should be developed.

\section{CONCLUSION}

We show that the degree of weakness and not spasticity predicted wheelchair confinement. The inevitable picture of motor impairment leads to the decreased ability to perform daily activities with impact on the patient's quality of 
life. On the other hand, the identification of the specific muscles affected in HAM/TSP enables early physical therapy intervention with a focus on strengthening of the lower limb muscles, especially the flexor knee and dorsalis flexor groups. The functional approach considering rehabilitation may be crucial to reduce the risk of complications, increase the patient's independence performing daily activities (mainly gait disability) and improving the social and functional aspects involved in the quality of life.

\section{Acknowledgments}

This work was supported by Fundação de Amparo à Pesquisa do Estado do Rio de Janeiro (FAPERJ) and a Msc fellowship from Coordenação de Aperfeiçoamento de Pessoal de Nivel Superior (CAPES) to R.C.C. We also thank Rosangela Martins from Research Division of the Hospital Universitário Clementino Fraga Filho/Universidade Federal Rio de Janeiro (UFRJ) for bioestatistical analysis.

\section{References}

1. Osame M. Review of WHO Kagoshima meeting and diagnostic guidelines for HAM/TSP. In: Blattner W, editor. Human retrovirology: HTLV. New York: Raven; 1990. p. 191-7.

2. Castro-Costa CM, Araújo AQ, Menna-Barreto M, Penalva-de-Oliveira AC. [Guide of clinical management of HTLV patient: neurological aspects]. Arq Neuropsiquiatr. 2005;63(2B):548-51. Portuguese. doi:10.1590/S0004-282X2005000300036

3. Gessain A, Cassar Olivier. Epidemiological aspects and world distribution of HTLV-1 infection. Front Microbiol. 2012;3:388. doi:10.3389/fmicb.2012.00388

4. Casseb J. Is human T cell lymphotropic type 1 (HTLV-1) associated myelopathy/tropical spastic paraparesis (HAM/TSP) syndrome a neglected disease? PLoS Negl Trop Dis. 2009;3(11):e487. doi:10.1371/journal.pntd.0000487

5. Franzoi AC, Araújo AQ. Disability and determinants of gait performance in tropical spastic paraparesis/HTLV-I associated myelopathy (HAM/TSP). Spinal Cord. 2007;45(1):64-8. doi:10.1038/sj.sc.3101919

6. Gessain A, Gout O. Chronic myelopathy associated with human T-lymphotropic virus type I (HTLV-I). Ann Intern Med. 1992;117(11):933-46. doi:10.7326/0003-4819-117-11-933

7. Martins JV, Baptista AF, Araújo AQ. Quality of life in patients with HTLV-I associated myelopathy/tropical spastic paraparesis. Arq Neuropsiquiatr. 2012;70(4):257-61. doi:10.1590/S0004-282X2012005000006

8. Medical Research Council of the United Kingdom. Aids to examination of the peripheral nervous system. Palo Alto, Califórnia: Pedragon House; 1978. (Memorandum, n. 45).

9. Daniels L, Worthingham C. Muscle testing: techniques of manual examination. Philadelphia:WB Saunders; 1986.

10. Ashworth B. Preliminary trial of carisoprodal in multiple sclerosis. Practioner. 1964;192:540-2.
11. Bohannon RW, Smith MB. Interrater reability of a modificated Ashworth scale of muscle spasticity. Phys Ther. 1987;67:206-7.

12. Mahoney FI, Barthel DW. Functional evaluation: Barthel index. Md State Med J. 1965;14:61-5.

13. Ciconelli RM, Ferraz MB, Wilton S, Meinão I, Quaresma MR. Tradução para língua portuguesa e avaliação do questionário genérico de avaliação de qualidade de vida SF-36 (Brasil SF-36). Rev Bras Reumatol. 1999;39(3):143-50.

14. Carod-Arthal FJ, Mesquita HM, Ribeiro LS. Manifestaciones neurológicas y discapacidad em pacientes que padecen mielopatía associada al HTLV-I. Neurologia. 2007;22(2):78-84.

15. Sheean G, McGuire JR. Spastic hypertonia and movement disorders: pathophysiology, clinical presentation, and qualification. PM R. 2009;1(9):827-33. doi:10.1016/j.pmrj.2009.08.002

16. William WC. De Jong's The neurologic examination. 7rd ed. Philadelphia: Lippincott Williams \& Wilkins; 2013.

17. Jansen K, De Groote F, Aerts W, De Schutter J, Duysens J, Jonkers I. Altering length and velocity feedback during a neuro-musculoskeletal simulation of normal gait contributes to hemiparetic gait characteristics. J Neuroeng Rehabil. 2014;11(1):78. doi:10.1186/1743-0003-11-78

18. Ward AB. Spasticity treatment with botulinum toxins. J Neural Transm (Vienna). 2008;115(4):607-16. doi:10.1007/s00702-007-0833-2

19. Coutinho IJ, Galvão-Castro B, Lima J, Castello C, Eter D, Grass MFR. Impact of HTLV-associated myelopathy/T tropical spastic paraparesis (HAM/TSP) on activities of daily living (ADL) in HTLV-1 infected patients. Acta Fisiatr. 2011;18(1):6-10. doi:10.5935/0104-7795.20110001

20. Shublaq M, Orsini M, Puccioni-Sohler M. Implications of HAM/ TSP functional incapacity in the quality of life. Arq Neuropsiquiatr. 2011;69(2A):208-11. doi:10.1590/S0004-282X2011000200013 